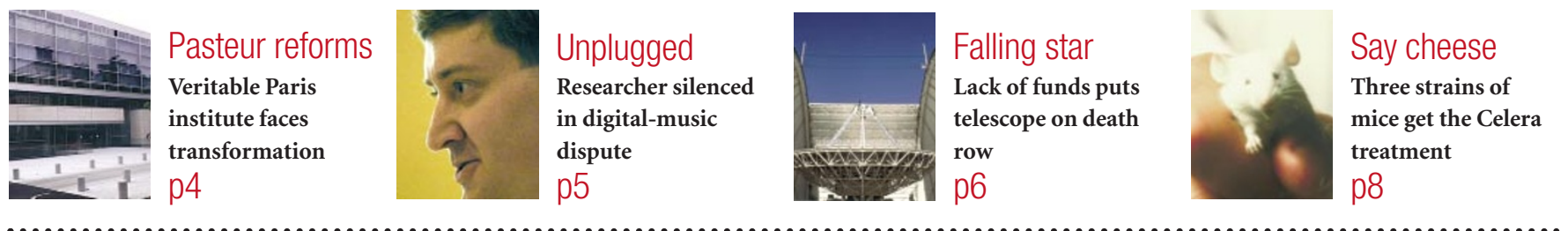

\title{
Study says authors are averse to declaring conflicts of interest
}

Jonathan Knight, San Francisco

Authors are ignoring journal policies that require them to state any conflict of interest over their papers, a new study suggests. But editors of leading journals disagree about whether this poses a real problem and, if it does, what to do about it.

The study, from Tufts University in Massachusetts, examined 61,134 articles that appeared in 1997 in 181 leading journals that had disclosure policies. The journals examined included Science, The Journal of the American Medical Association and Proceedings of the National Academy of Sciences. But Nature and Cell, for example, did not have disclosure policies, and so were excluded.

The researchers counted every occurrence of a positive disclosure, including honoraria, patents pending, stock holdings or other forms of personal or financial interest. The research appears in Science and Engineering Ethics (7,205-218;2001). Only a third of the journals surveyed contained papers carrying any disclosure. Of those, fewer than $1 \%$ of papers contained a disclosure.
A possible explanation is that few researchers had anything to disclose. But the study's lead author, Sheldon Krimsky of Tufts' Department of Urban and Environmental Policy, says this is unlikely. "What is the chance that in two-thirds of the journals there was no one with a patent, equity interest or honorarium?"he asks.

But some journal editors say that such information is of little value to readers. Kevin Davies, editor-in-chief of Cell Press, says editors usually consider that good science stands on its own merits. "It's the quality of the research that counts," he says.

Science's editor-in-chief Donald Kennedy agrees. But the journal's authors must provide information on potential conflicts of interest. These disclosures are reviewed by editors, but not given to external reviewers. "The peer reviewers' job is to evaluate the science

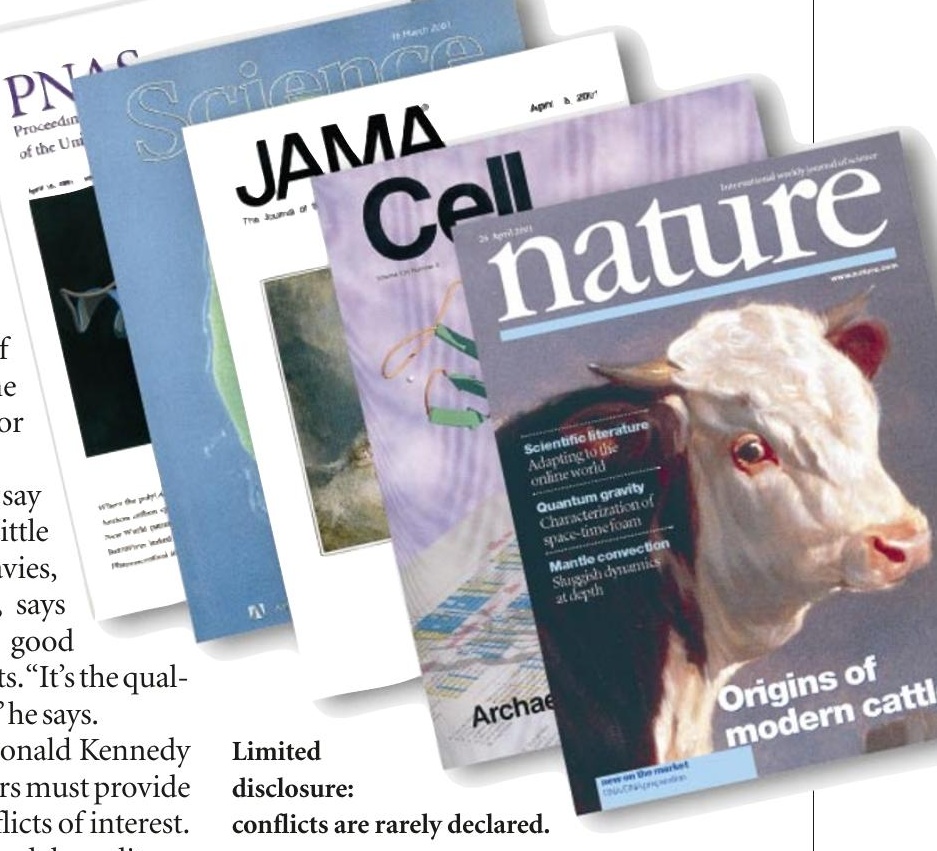

and not to be our ethicists," he says.

But Krimsky argues that complete

\section{Bills threaten total US ban on human cloning}

\section{Meredith Wadman, Washington}

Republicans in the US Congress have proposed two far-reaching bills that would outlaw the cloning of human cells, regardless of whether they were to be used in research or reproduction.

Senator Sam Brownback (Republican, Kansas) and Representative Dave Weldon (Republican, Florida) introduced the Human Cloning Prohibition Act of 2001 on 26 April. It bans both publicly and privately funded human cloning based on somaticcell nuclear transfer, the technique used to produce Dolly the sheep. It also bans importation of any "product of human cloning for any purpose".

Those breaking the law would face a fine of at least \$1 million, a prison sentence of up to 10 years, or both. Another bill, introduced on the same day by Vernon Ehlers

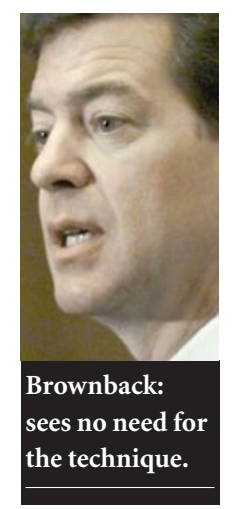

(Republican, Michigan), one of a handful of scientists in the Congress, also criminalizes human cloning for any purpose. Scientists hope that cloned embryos might serve as a source of stem cells for treating a range of diseases, including diabetes and Parkinson's. But harvesting the cells means destroying the embryo, which has generated objections from opponents of abortion.

In theory, the embryos could also be used to generate a cloned human being. Already a team of infertility doctors and a cult called the Raelians have announced that they will attempt to produce cloned human beings in the near future (see Nature 410, 617; 2001).

"There is no need for this technology to ever be used with humans - whether for reproductive purposes or for destructive research purposes," Brownback said in introducing his bill.

Anti-abortion groups have embraced the bill. But scientists are responding with concern. It "unnecessarily limits important medical research", says Elizabeth Marincola, the executive director of the American Society for Cell Biology. "Such a sweeping bill is not necessary" to protect against cloning a human being, she says.

The extent to which cloning should be outlawed is dividing Republicans in the Congress. Moderate Republicans are expected to back a more narrowly written bill that would preserve the cloning of embryos for research. 
disclosure would help to ensure fair review. "If the article is on a safe cigarette, it would help the reviewer to know if that person had been in the public sector or employed by a cigarette company for 20 years," he says.

The Proceedings of the National Academy of Sciences requires contributors to disclose relevant commercial ties. But not all authors respond to the requirement without prompting, according to editorin-chief Nicholas Cozzarelli. The journal has on occasion published corrections noting an undisclosed conflict of interest after vigilant readers complained.

Cozzarelli says the problem is one of differing interpretations of what constitutes a conflict of interest rather than any intent by authors to hide the truth.

Nature's lack of disclosure requirement is set to change, according to its editor Philip Campbell. Later this year, all Nature journals will ask contributors to declare any financial interest in the research they submit for publication. Contributors will have the option not to declare, but this will also be noted in the paper, Campbell says.

The shift is partly in response to evidence that financial ties do matter. For example, a study in The Journal of the American Medical Association (282, 1453-1457; 1999) found that research funded by pharmaceutical companies was eight times more likely than publicly funded research to reach a favourable conclusion about the usefulness of a drug.

Although the evidence is not conclusive, recent debates on genetically modified crops, for example, have highlighted public concerns about a possible undermining of scientific independence, says Campbell. "Transparency about financial interests should help to minimize such concerns," he says.

\section{Pasteur turns to biotech firms in bid to revitalize research}

\section{Sally Goodman, Paris}

Stung by criticism in a recent external review, the Pasteur Institute is implementing a range of reforms, including a biotechnology 'incubator unit', aimed at sparking a more entrepreneurial spirit among its scientists.

The incubator - Pasteur BioTop - is part of a reform programme instigated last year by director-general Philippe Kourilsky (see Nature 405, 990; 2000). It will eventually house 10 biotechnology start-ups, each with a two-year contract with the institute.

One of France's leading centres for biomedical research, the Pasteur Institute has an annual budget of nearly FFr1 billion (US\$135 million), operating 110 research laboratories in central Paris with 2,500 staff. Income from patents and other industrial sources cover about $40 \%$ of its costs, but it faces budgetary pressure as a number of its most important patents are due to expire.

André Choulika, head of Cellectis, a genomics engineering business and one of three start-ups already housed in the incubator, says that the project has given a new lease of life to the institute.

Philip Avner, a genome researcher at the institute, agrees. "Now people who would never have had the opportunity to collaborate can have a go, and this has given a certain dynamic to the institute," he says.

But not all researchers are thrilled by the introduction of private businesses to the institute. "The Pasteur Institute risks losing its soul and originality by following fashion," said one, who declined to be identified.

Other elements of Kourilsky's reforms include changes in departmental structure and a major recruitment exercise. A recent external evaluation of the institute, led by Harold Varmus, former director of the US National Institutes of Health, was critical of the existing structure. It said that a lack of coherence in the research areas handled by the different departments was stifling emerging talent at the institute. The report also criticized shortcomings in the Pasteur's recruitment, training and evaluation policies.

A new structure will be implemented next year, with a larger number of more tightly focused departments. Cross-disciplinary programmes are also being developed, and around 50 new research groups will be created over the next 10 years, led by young researchers recruited after an international call for proposals.

As part of the plan to attract new blood to the institute, a scholarship scheme to recruit and fund postdocs for specific research projects is also being planned.

http://www.pasteur.fr

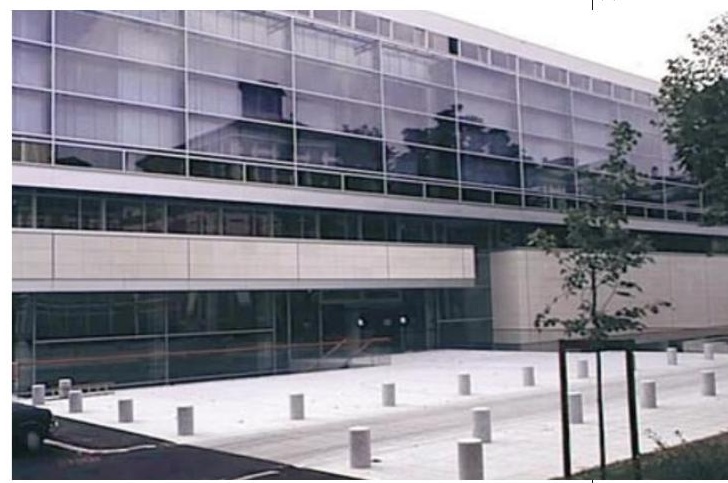

All change: the Pasteur Institute is attempting to capture a more entrepreneurial spirit.

\section{Congress hints at brighter outlook for physical science}

Irwin Goodwin, Washington

Members of the Congress are backing scientists in their demands for more research funding for 2002 than has been proposed by President George W. Bush particularly in the physical sciences.

At a meeting of the House of Representatives Science Committee on 25 April with the heads of four research agencies, chairman Sherwood Boehlert (Republican, New York) called next year's budget "particularly disappointing". He said the administration had already "signalled repeatedly that the numbers will be better next year, particularly for the National Science Foundation"(NSF), but added that researchers should not have to wait until then for better funding.

Boehlert and other Republican committee members, in particular Connie Morella (Maryland) and Vernon Ehlers (Michigan), said they were pressing their party leaders in Congress and the White House to raise the budgets for the science agencies.

The committee asked the agency officials present, who included James Decker of the Department of Energy, the NSF's Rita Colwell and Dan Goldin of NASA, to identify programmes that would be cut or reduced to meet the budget proposal, but they declined to do so. Boehlert said he understood their reluctance, but later described the budget proposal as "grossly inadequate".

Various committees in Congress are now considering next year's funding levels for research and other spending priorities. They will agree a final budget with Bush around the start of the 2002 fiscal year on 1 October.

In the Senate, the Budget Committee's chairman Pete Domenici (Republican, New Mexico) has complained of nearly flat funding for the energy department's science office.

An amendment to the Senate's budget resolution, calling for $\$ 1.4$ billion more science funding at the energy department, NASA and NSF, was passed last month. 